\title{
Bacteriological Quality of Street Vended Ready to Eat Legume and Vegetable Based Foods in Bahir Dar Town, Amhara Regional State, North Western Ethiopia
}

\author{
Mohammed Tesfaye \\ Department of Biology, Assosa University, Ethiopia
}

\begin{abstract}
Street vending foods are readily available sources of meals for many people, but the micro- biological quality of such foods have been always in doubt. The aim of this study was to determine the microbial quality of legume and vegetable based foods and the hygienic practices of street legume and vegetable based foods in Bahir Dar town. Sixty food samples were collected from different locations for Aerobic mesophilic, total coliforms, fecal coliforms and Staphylococcus aureus counts based on standard methods from December 2012 to July 2013. Out of the total samples, $28.3 \%, 33.3 \%, 18.3 \%$ and $51.7 \%$ of the foods were above acceptable limit for aerobic mesophilic count, S. aureus, total coliforms and thermotolerant, respectively. While S.aureus and thermotolerant coliforms were not detected in $1(21.7 \%)$ and $29(48.3 \%)$ of the food samples, respectively. Only $7(11.7 \%)$ of the total sample was hazardous due to high mean count of S. aureus. There were no statistically significance differences $(p>0.05)$ in bacterial counts between the two food groups. On the other hands, most of the water samples used to wash ready to eat foods and utensils in food preparation were contaminated and above WHO drinking water standards. In addition, an observational checklist shows a majority of the handlers did not practice hand washing during food preparation and without reheating to serve prepared foods. Most of the readyto-eat foods were contaminated and they can pose potential risks to consumers and therefore it requires the local authority emphasize on educating the ready-to-eat food handlers on food and personal hygiene to ensure the hygienic standards and food safety.
\end{abstract}

Keywords:Bacterial count, Coliform, Contamination, Food hygiene, Street food

DOI: $10.7176 / \mathrm{JBAH} / 9-1-08$

\section{INTRODUCTION}

Street-vended foods are foods and beverages prepared and sold by vendors in the streets and other public places for immediate consumption or consumption at a later time without further processing or preparation (Thomas, 2010; Ackah et al., 2011; Garode and Waghode, 2011). These foods may be consumed at the same place or can be taken away and consumed elsewhere. Street vended foods are not only appreciated for their unique flavors, convenience and the role they play in the cultural and social heritage of societies, but also become important and essential for maintaining the nutritional status of the population (Garode and Waghode, 2011). At present, street food offers a chance for self-employment and to develop business skills with low capital investment (Draper, 1996; Thomas, 2010; WHO, 2010). In addition, the street food industry feeds millions of people daily with a wide variety of foods that are cheap and easily accessible (Garode and Waghode, 2011).

On the other hands, street foods show great variation in terms of ingredients, processing, and methods of marketing and consumption. They often reflect traditional local cultures and exist in an endless variety encompassing meal, drinks and snacks. These categories reflect a growing difficulty to provide adequate infrastructure and environmental hygiene to ensure the safe production of food (Leonard et al., 2003). There is much diversity in the raw materials as well as in the method of preparation of street foods and there are also differences in the places where street foods are prepared; however, the majority of the vendors, prepared their food at home and brought to the streets for marketing (Leonard et al., 2003; WHO, 2010).

Epidemiological studies suggest that street foods contribute to a significant number of food poisonings are inadequate, due to paucity of data in knowledge about important parameters in the food chain and host pathogen interactions; however, there have been several documented cases of food poisoning outbreaks due to street foods (Umoh and Odoba, 1999). The people who depend on such foods are often more interested in its convenience than its safety or quality and hygienic aspects of the consumed food. Besides, the traditional processing methods that are used in the preparation, inappropriate holding temperature and poor personal hygiene of food handlers are some of the main causes of food borne illness of microbial origin and a major health problem associated with street foods (Feglo and Sakyi, 2012).

Food borne bacterial pathogens commonly detected in street vended foods are B. cereus, C. perfringens, S. aureus and Salmonella spp. (Umoh and Odoba, 1999; Deriba and Mogessie, 2001). People, who patronize street food, have been reported to suffer from food borne diseases like diarrhea, cholera, typhoid fever and food poisoning (Kaul and Agarwal, 1998).

Heavily contaminated water which used for food preparation and drinking is also a primary source of 
diarrheal diseases to the street food consumers. Pathogens like Salmonella and Shigella have been detected in the water used by vendors for dishwashing (Barro et al., 2006). Similarly, studies done to find out the bacteriological quality of the water used by some street vendors have revealed frequent contamination with coliforms and fecal coliforms (Agard et al., 2002).

Among the traditional foods throughout Ethiopia, vegetables and legumes based foods are the most popular dishes and the vendors sell foods throughout the day along with local pancake like bread called Ingera. Different researchers in the country revealed that pathogens and indicators are enumerated above the acceptable limit from different categories of street vended foods. Study done in Jemma town, Staphylococcus count in street foods was much higher $(5.39 \log \mathrm{cfu} / \mathrm{ml})$ than the standard and dominated by almost the same load of aerobic mesophilic bacteria (6.13 $\log \mathrm{cfu} / \mathrm{ml}$ ) and Enterobacteriacae (5.96 $\mathrm{log} \mathrm{cfu} / \mathrm{ml})$ (Tekletsadik and Tsige, 2011). Additionally, according to Deriba and Mogessie (2001), from a total of 150 samples were collected from different outlets in Addis Ababa, most of the street food samples had aerobic mesophilic counts $>10^{7} \mathrm{cfu} / \mathrm{g}$. On the other hand, a study done in Bahir Dar town, the total coliform counts on the surface and the core of street vended white lupin ranged from 15 to $1100 \mathrm{MPN} / \mathrm{g}$ and 11 to $1100 \mathrm{MPN} / \mathrm{g}$, respectively; and out of $40 \mathrm{samples,} 92.5 \%$ of the surface and the core was contaminated with fecal coliforms (Mulugeta and Million, 2013).

In Bahir Dar town, different types of ready to eat foods are commonly sold near the streets, taxi ranks and bus station, market centers and other public areas. Researches were done on microbiological quality and safety of some ready to eat foods in the city (Alemayehu, 2011; Mesfin, 2011; Mastewal, 2011).However, there is no information on microbiological quality and safety of cooked legume and vegetable based foods sold in the streets of Bahir Dar town. Therefore, the present study was conducted; to determine bacterial detection and count in relation to food quality as well as water quality which used for food preparation and washing equipments along with the hygiene and handling practices of food handlers.

\section{MATERIALS AND METHODS}

\subsection{Description of the study area}

The study was conducted in Bahir Dar city, the capital of the Amhara, National Regional State in the Northern part of Ethiopia. It is located at $11^{\circ} 38^{\prime} \mathrm{N}, 37^{\circ} 10^{\prime} \mathrm{E}$ on the southern side of Lake Tana (http:/en.wikipediaorg/wiki Bahir Dar). The lowest and the highest annual average temperatures of the city are $10.3^{\circ} \mathrm{C}$ and $26.3^{\circ} \mathrm{C}$, respectively. The annual average rainfall is 1,224mm (Bahir Dar City Administration, 2009). Bahir Dar is one of the leading tourist destinations in Ethiopia, with a variety of attractions in the nearby Lake Tana and Blue Nile River. Street food vendors in the city around main road, bus station and hospital areas are common practice

\subsection{Study design}

A cross-sectional prospective study was conducted in Bahir Dar city from December 2012 to July 2013 to assess the bacteriological quality of street vended legume and vegetable based foods in three purposive selected sites within assessing of handling practices of food vendors

\subsection{Sample description and collection of food sample}

Commonly served ready to eat foods (RTE) in the street vendor; legume based (made from roasted and ground faba bean or split pea or lentil) and vegetable based (a classic dish made from cabbage, potato, carrot and kale flavored with spice). These foods are normally cooked at over $85^{\circ} \mathrm{C}$ for $30-60$ minutes or even longer and after cooling the food to be ready to serve and sell throughout the day by venders without reheating. A total of 60 samples (30 legume-based and 30 vegetable based foods) were collected from each of the three sampling locations (around Bus station, Belay zeleke kebele and Hospital) in the town and stored in refrigerator until bacteriological analysis was carried out within an hour of collection.

\subsection{Microbiological analysis of food}

\subsubsection{Enumeration of aerobic mesophilic bacteria}

The total count of aerobic mesophilic bacteria was determined as the procedure described by (Kiiyukia, 2003; Azanza, 2005). One milliliter from each decimal dilution up to $10^{-3}$ was dispensed into triplicate sterilized Petri dishes and plate count agar was poured and incubated at $37^{\circ} \mathrm{C}$ for 48 hours.

\subsubsection{Total coliforms and fecal coliforms}

Test for the presence of total coliforms and fecal coliforms in the food samples was based on the procedure described in the Manual of Food Quality Control of FAO (Andrews, 1992). And the results of the test were reported as the most probable number (MPN) per gram of food. The same procedure was carried out for fecal coliforms except incubated period for both presumptive and confirmatory tests.

\subsubsection{Staphylococcus aureus}

One $\mathrm{ml}$ in each sample of prepared serial dilution was transferred into triplicate sterile Petri dishes and Mannitol salt agar (Oxoid, England) was poured and swirled gently and finally incubated at $37^{\circ} \mathrm{C}$ for a maximum of 48 
hours (Robers and Greenwood, 2003). Yellow and orange colonies surrounded by yellow zones due to mannitol fermentation were enumerated and reported as mean $\mathrm{cfu} / \mathrm{g}$ of food.

\subsection{Bacteriological analysis of water}

Two hundred (200) $\mathrm{ml}$ of each water sample was collected in a sterile glass bottle from each location and were transported into the laboratory followed by bacteriological analysis for total coliforms according to the procedure described by APHA (Adetunde and Glover, 2011) and results reported as MPN/100ml.

\subsection{Assessments of the hygienic practices of venders and vending area}

The observation checklist covering topics on the personal hygiene of the food handlers, food hygiene practices (modes of cleaning and sanitizing utensils) and hygiene of the cooking area to assess whether the vending food exposed to flies, insects and animals, presence of solid and liquid waste and latrine facilities around the food vending area.

\subsection{Data analysis}

t-test was used if there is a statically significance difference between the two food items for microbial load. One way ANOVA using SPSS software version 20 was also to compare mean bacterial counts of food samples from different locations. Significance of difference held, at $\mathrm{p}<0.05$.

\section{RESULTS AND DISCUSSION}

\section{Aerobic mesophilic counts}

In the present study, the range of aerobic mesophilic bacteria was 3.28 to $5.95 \log 10 \mathrm{cfu} / \mathrm{g}$ with a mean value of $4.50 \log 10 \mathrm{cfu} / \mathrm{g}$ in legume based and 2.72 to $5.79 \log 10 \mathrm{cfu} / \mathrm{g}$ with a mean value of $4.54 \log 10 \mathrm{cfu} / \mathrm{g}$ in vegetable based food (Table 1). There is no statistically significant difference between the mean bacterial count of legume and vegetable based foods (i.e., $p=0.850)$. The mean count of aerobic mesophilic bacteria of legume based (4.50 $\log \mathrm{cfu} / \mathrm{g}$ ) and vegetable based (4.54 $\log \mathrm{cfu} / \mathrm{g}$ ) foods in this study fall under acceptable limit and compared to this finding with the study done in Cape Coast, Ghana was revealed that legume based foods of microbial contamination ranges from 4.41 to $7.11 \log 10 \mathrm{cfu} / \mathrm{g}$ with mean of $5.8 \log 10 \mathrm{cfu} / \mathrm{g}$ (Annan et al., 2011) which exceed the acceptable level $(<5 \log 10 \mathrm{cfu})$ and another study of fully processed food of legume based dish in Nigeria, AMC ranges from 3.74 to $5.08 \log 10 \mathrm{cfu} / \mathrm{g}$ with a mean value of $5.48 \log 10 \mathrm{cfu} / \mathrm{g}$ (Bukar et al., 2010).

Table 1: Mean and range of aerobic mesophillic bacteria $(\log 10 \mathrm{cfu} / \mathrm{g})$ of street vended legume and vegetable based foods in Bahir Dar town $(n=60)$

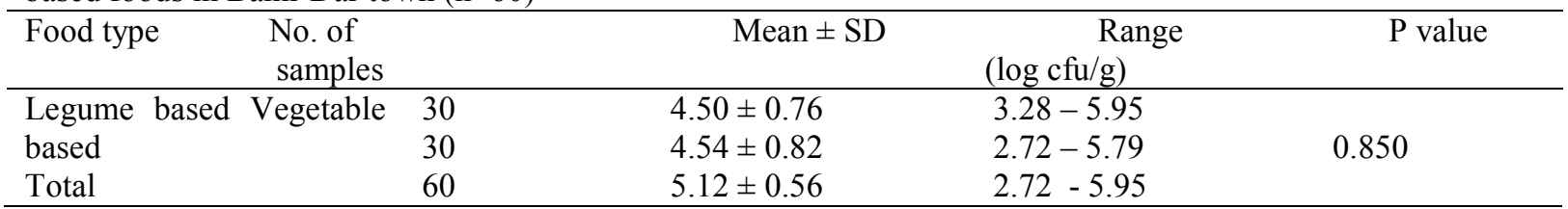

As shown in Table 1, total mean AMC of street vended foods (5.12 log cfu/g) fell above the standard limit $(\geq 5 \log 10 \mathrm{cfu} / \mathrm{g}$ ) set by PHLS (2000) and NSW(2009) which categorized as unsatisfactory for consumption and similarly agreed to study conducted by Azanza (2005) and Tambekar et al. (2009). On the other hand, all food samples were positive for mesophilic bacteria (Table1) whereas Mensah et al. (2002) reported that of 511 street food items examined in Accra, only 69.7\% contained mesophilic bacteria.

The current study has a low mean bacterial count compared to the study done in South Africa, the mean value of aerobic bacterial count of vegetables was $6.8 \log 10 \mathrm{cfu} / \mathrm{g}$ with a range of $6.3-6.8 \log 10 \mathrm{cfu} / \mathrm{g}$ (Mirriam et al., 2012) whereas in this study had a higher mean bacterial count of legume based $(4.50 \log 10 \mathrm{cfu} / \mathrm{g})$ than study conducted in street foods in Accra, Ghana $(2.5 \log 10 \mathrm{cfu} / \mathrm{g} \pm 0.03 \mathrm{SD}$ ) of aerobic mesophilic count (Mensah et al., 2002). Similarly, the aerobic count of the present study in both food types had higher mean value than the study done in Sudan revealed that the mean total viable count of cooked vegetable sauce and legume based food (foul) was 4.5 and $4.2 \log 10 \mathrm{cfu} / \mathrm{g}$, respectively (Abdella et al., 2009).

It is believed that high aerobic mesophilic bacteria in foods indicate greater risks of pathogens being present in consumable products, poor implementation of sanitation procedures or problems in process controls, temperature abuse during vending and inadequate cooking (Azanza, 2005). In the current study, 43/60 (71.7\%) in which $14(23.3 \%)$ and $29(48.3 \%)$ of the total sample categories as good, and acceptable, respectively, and therefore, most of the food samples were satisfactory for consumption and the remaining 17/60 (28.4\%) categorized as unsatisfactory or above accepted limits (Table 2). 
Table 2: The number and percentage of good, acceptable and unsatisfactory level of AMC in street vended legume and vegetable based foods in Bahir Dar

\begin{tabular}{clllll} 
Parameter & \multicolumn{1}{c}{ Food type } & \multicolumn{1}{c}{ Good (\%) } & Acceptable (\%) & \multicolumn{1}{c}{$\begin{array}{c}\text { Unsatisfactory } \\
(\%)\end{array}$} & Total \\
AMB & Legume & $8(26.7 \%)$ & $14(46.6 \%)$ & $8(26.7 \%)$ & 30 \\
& Vegetable & $6(20 \%)$ & $15(50 \%)$ & $9(30 \%)$ & 30 \\
Total & & $14(23.3 \%)$ & $29(48.3 \%)$ & $17(28.4 \%)$ & 60 \\
\hline
\end{tabular}

AMB* Aerobic-mesophilic bacteria

The finding of the result showed that higher mean counts of aerobic mesophilic bacteria was recorded in vegetable $(5.02 \log 10 \mathrm{cfu} / \mathrm{g})$ followed by legume based $(4.72 \log 10 \mathrm{cfu} / \mathrm{g})$ from Bus station. Whereas, the lowest mean value of AMC was obtained from vegetable based food (4.12 $\log 10 \mathrm{cfu} / \mathrm{g})$ from Belay zeleke kebele and legume based food (4.32 $\log 10 \mathrm{cfu} / \mathrm{g})$ from hospital surroundings. Even though mean variation among sites, there is no statistically significance difference of mean aerobic bacterial count $(f=0.707 ; p=0.502)$ in legume based food. But statistical significance difference of the mean aerobic count was obtained in vegetable based food $(\mathrm{f}=3.632 ; \mathrm{p}=0.04)$ among sites (Figure 1).

Figure 1: Aerobic mesophillic bacteria $(\log 10 \mathrm{cfu} / \mathrm{g})$ of street vended legume and vegetable based foods among three sites in Bahir Dar town

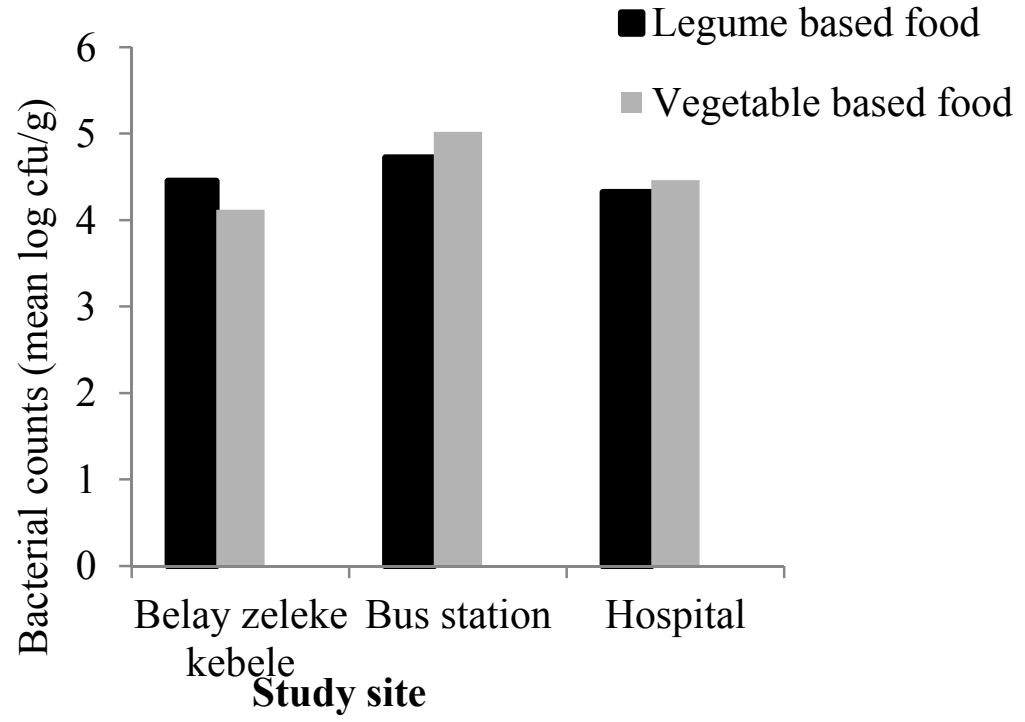

The differences of AMC among the study sites may be due to variations in hygienic condition of the vending environment and practices of the food vendors. The highest count around Bus station may be due to the venders achieved their daily activities under crowded area and poor practice of garbage disposals around the vending area. Similarly, study in Nigeria to analyze the microbial quality of RTE foods revealed that the vegetables recorded the highest $\left(1.8 \times 10^{6} \mathrm{cfu} / \mathrm{g}\right)$ bacterial population in one study location than the others (Odu and Akano, 2012).

\section{Total coliform counts}

The present study demonstrated that total coliform counts of legume based food range from 3.6 to 1100 with mean value of $231.4 \mathrm{MPN} / \mathrm{g}$; and in vegetable based food range 7.2 to 1100 with mean of $308.6 \mathrm{MPN} / \mathrm{g}$. However, there was no statistically significant variation in coliform counts between food types $(\mathrm{p}=0.467)(\mathrm{Table}$ 3).

Table 3: Mean and range of total coliform count (MPN/g) of street vended legume and vegetable based foods in Bahir Dar town $(\mathrm{n}=60)$

\begin{tabular}{lllllc}
\hline \multicolumn{1}{c}{ Food type } & \multicolumn{1}{c}{ No. of samples } & Mean & Minimum & Maximum & P value \\
\hline Legume based & 30 & 231.4 & 3.6 & 1100 & 0.467 \\
Vegetable based & 30 & 308.6 & 7.2 & 1100 & \\
\hline Total & 60 & 554.6 & 3.6 & 1100 & \\
\hline
\end{tabular}

The presence of indicator bacteria in RTE food, although not inherently a hazard, can be indicative of poor practice that may be one or more of the following (Roberts and Greenwood, 2003); poor environmental sanitation is largely responsible for much of the contamination, and poor personal hygiene, particularly among food handlers, accounts specifically for the contamination of foods while improper storage leads to multiplication of bacteria in food to infective doses. Foods are often preserved at ambient temperatures, long 
before consumption, improperly handled by food vendors, and sold in streets in the dirty and unhygienic environment (Roberts and Greenwood, 2003).

The finding of the study also revealed that $37(61.7 \%), 12(20 \%)$ and $11(18.3 \%)$ out of the total samples had levels of coliform contamination as good, acceptable and unsatisfactory, respectively in which $5(16.7 \%)$ in legume based and $6(20 \%)$ in vegetable based food; above the accepted limit $(\geq 1000 \mathrm{MPN} / \mathrm{g})$ recommended by the Food Quality Check Program (2011) fell within unsatisfactory for consumption (Table 4). Presence of coliforms in street foods might also be due to inadequate handling, water used for food preparation and serving which may be contaminated with fecal coliforms (Gitahi et al, 2012).

Table 4: The number and percentage of good, acceptable and unsatisfactory level of total coliforms count in street vended legume and vegetable based foods in Bahir Dar town.

\begin{tabular}{llllll}
\hline Parameter & Food type & Good (\%) & Acceptable & \multicolumn{1}{c}{ Unsatisfactory } & Total \\
\hline Total- & Legume & $21(70 \%)$ & $4(13.3 \%)$ & $5(16.7 \%)$ & 30 \\
coliforms & Vegetable & $16(53.3 \%)$ & $8(26.7 \%)$ & $6(20 \%)$ & 30 \\
Total & & $37(61.7 \%)$ & $12(20 \%)$ & $11(18.3 \%)$ & 60 \\
\hline
\end{tabular}

As shown in (Figure 2), the mean values of total coliforms of legume based food samples obtained from Belay zeleke kebele, Bus station and Hospital surrounds were 144.4, 372.4 and $177.6 \mathrm{MPN} / \mathrm{g}$, respectively, whereas mean total coliforms in vegetable based food were 220.2, 409 and $296.5 \mathrm{MPN} / \mathrm{g}$, respectively. However, there was no statically significant difference in legume based food $(\mathrm{f}=0.931 ; \mathrm{p}=0.406)$ and vegetable based food $(\mathrm{f}=0.510 ; \mathrm{p}=0.606)$ among the sites. The mean value of total coliform among sites in the present study in both food types fall into acceptable limit $(>100 \mathrm{MPN} / \mathrm{g})$ whereas other study demonstrate that total coliforms were detected in vegetables of all locations at unsafe levels and the lowest counts of total coliforms were in legume based foods (Gitahi et al., 2012).

Figure 2: Total coliforms count (MPN/g) of legume and vegetable based foods among three sites in Bahir Dar town

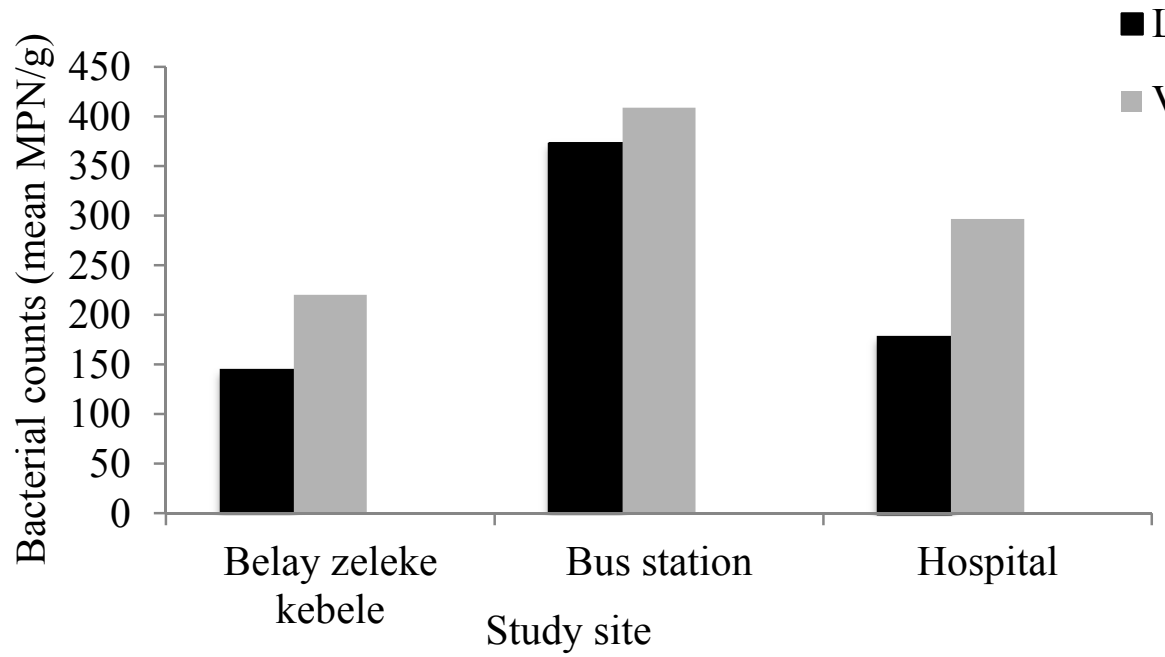

Legume based food

Vegetable based food

\section{Fecal (Thermotolerant) coliforms count}

Fecal coliforms (thermotolerant coliforms) are more restricted in their source to the gastrointestinal tract of warm-blooded animals. Their presence in ready to eat foods could indicate fecal contamination and sometimes the presence of pathogens. Fecal contamination can arise through the use of contaminated water, poor hygiene of food workers in contact with the food product, or through contact with flies or other insect pests (Nawas et al., 2012).

In this study, the mean of fecal coliform counts of the legume based food was 23.46 with a range of 3 to $120 \mathrm{MPN} / \mathrm{g}$ and similarly the mean count of vegetable food were 27.08 with a range of 3.6 to $240 \mathrm{MPN} / \mathrm{g}$ (Table 5). Although mean variation between food items, there was no statistical significant differences between mean fecal coliforms count between the foods $(\mathrm{p}=0.835)$. The present study had comparatively higher maximum value (240MPN/g) than the study carried out in Nigeria by Odu and Akano (2012), revealed that, the fecal coliform count in vegetables ranged from 3.6 to $9.2 \mathrm{MPN} / 100 \mathrm{ml}$. 
Table 5: Mean and range of fecal coliforms count (MPN/g) of street vended legume and vegetable based foods in Bahir Dar town $(n=60)$

\begin{tabular}{lllllr}
\multicolumn{1}{c}{ Food type } & No. of samples & Mean & Minimum & Maximum & P value \\
\hline Legume based & 14 & 23.46 & 3 & 120 & 0.835 \\
Vegetable based & 17 & 27.08 & 3.6 & 240 & \\
\hline Total & 31 & 25.44 & 3 & 240 & \\
\hline
\end{tabular}

The present study also revealed that the percentage of vegetable and legume based foods contaminated by fecal coliforms were $13(43.3 \%)$ and $16(53.3 \%)$, respectively categorized as good and the remaining $14(46.7 \%)$ in legume based and $17(56.7 \%)$ in vegetable based food categorized as unsatisfactory. Nearly half of the samples $(48.3 \%)$ classified into satisfactory level and the remaining $(51.7 \%)$ as unsatisfactory for consumption (Table 6). Similarly, a study conducted in Pakistan; in six cooked vegetables only two samples were positive for fecal coliforms (Yasin et al., 2012)

Table 6: The number and percentage of good and the unsatisfactory level of fecal coliforms in street vended legume and vegetable based foods in Bahir Dar

\begin{tabular}{llllll}
\hline Parameter & Food type & Good (\%) & Acceptable (\%) & $\begin{array}{l}\text { Unsatisfactory } \\
(\%)\end{array}$ & Total \\
\hline & & & & & \\
Fecal- & Legume & $16(53.3 \%)$ & N/A & $14(46.7 \%)$ & 30 \\
coliforms & Vegetable & $13(43.3 \%)$ & N/A & $17(56.7 \%)$ & 30 \\
\hline Total & & $29(48.3 \%)$ & - & $31(51.7 \%)$ & 60 \\
\hline
\end{tabular}

N/A-Not applicable

The highest mean contamination of vegetable based samples by fecal coliforms was obtained in the cite Belay zeleke kebele (50.6 MPN/g), Hospital surround (17.6MPN/g) followed by Bus station (10.3MPN/g), whereas the legume based food had the highest mean count (MPN/g) at Belay zeleke kebele (28.3), Bus station (22.7) followed by Hospital surround (19.2 MPN/g) (Figure 3).

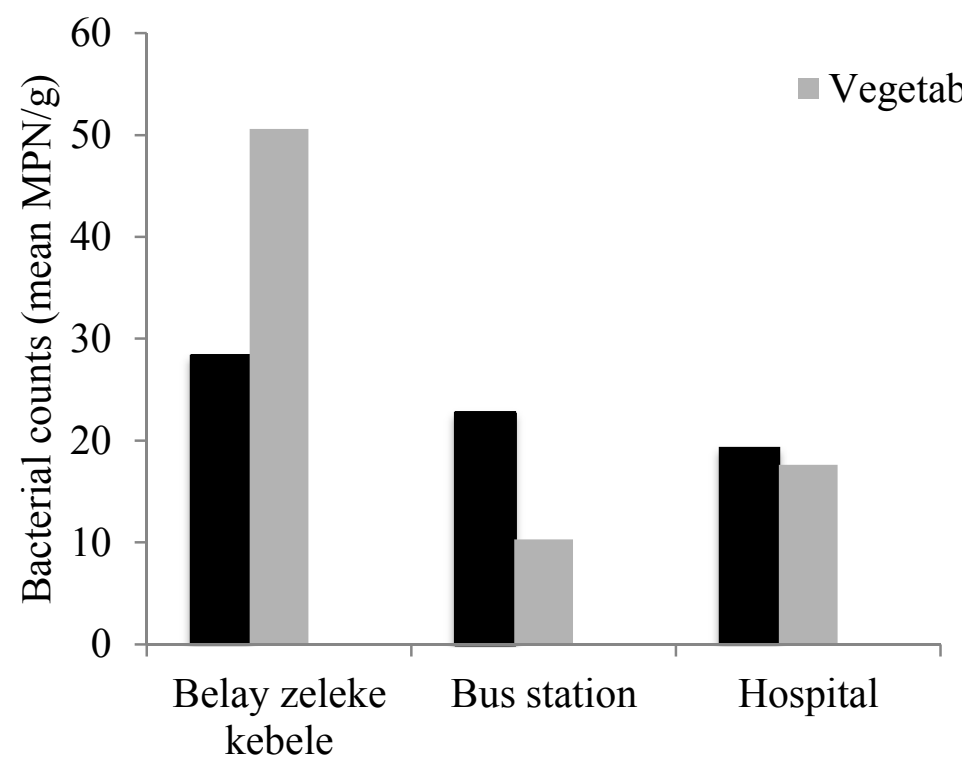

Study site

Figure 3: Fecal coliforms count (MPN/g) of legume and vegetable based foods among three sites in Bahir Dar town

There is no statically significant difference in legume based food $(\mathrm{f}=0.75 ; \mathrm{p}=0.929)$ and in vegetable based food among sites $(\mathrm{f}=0.815 ; \mathrm{p}=0.463)$. Overall, the presence of coliforms particularly in processed food which indicative of recent contamination and there is a greater risk of pathogens (Yasin et al., 2012).

\section{Staphylococcus aureus count}

The study showed that the mean value of legume and vegetable based food was 2.97 and $2.91 \log 10 \mathrm{cfu} / \mathrm{g}$ with range value of 1.74 to 4.52 and 1.50 to $4.24 \log 10 \mathrm{cfu} / \mathrm{g}$, respectively. There was no statistically significance difference in the mean count of $S$. aureus between the two food items $(\mathrm{p}=0.775)$ (Table 7). The present study agrees with the study carried out in Nigeria in which the range for staphylococci count of vegetables was 0 to $4.58 \log 10 \mathrm{cfu} / \mathrm{g}$ (Odu and Akano,2012). In the present study, the higher detection rate of couglase positive 
Staphylococcus was obtained from vegetable based sauce (86.7\%) than legume based foods $(70 \%)$ and compared to other study conducted in Taiwan, the percentage of positive samples of $S$. aureus in vegetable based food were $13.6 \%$ (Fang et al., 2003).

Table 7: Mean and range of $S$. aureus count $(\log 10 \mathrm{cfu} / \mathrm{g})$ of street vended legume and vegetable based foods in Bahir Dar town, $2013(\mathrm{n}=60)$.

\begin{tabular}{|c|c|c|c|c|}
\hline Food type & No. of samples & Mean $(\log \mathrm{cfu} / \mathrm{g}) \pm \mathrm{SD}$ & $\begin{array}{l}\text { Range } \\
(\log \mathrm{cfu} / \mathrm{g})\end{array}$ & $\mathrm{P}$ value \\
\hline Legume & based 21 & $2.97 \pm 0.87$ & $1.74-4.52$ & \multirow{3}{*}{0.775} \\
\hline Vegetable & 26 & $2.91 \pm 0.70$ & $1.50-4.24$ & \\
\hline Total & 47 & $2.78 \pm 0.68$ & $1.50-4.52$ & \\
\hline
\end{tabular}

S. aureus detected in food could possibly source from vendors' hands while cooking the food or through coughing and sneezing as well as storage of food at high temperature (Rabbi et al., 2011). The finding of the study had comparatively higher mean $\log 10 \mathrm{cfu} / \mathrm{g}$ of $S$. aureus in legume based foods than study done in street foods in Accra ( 0.6 mean $\log 10 \mathrm{cfu} / \mathrm{g}$ ) of $S$. aureus (Mensah et al., 2002) while mean $S$. aureus count was lower in both food types than the study conducted in Sudan, $S$.aureus count of cooked vegetable sauce and legume food was 3.1 and $3.2 \log 10 \mathrm{cfu} / \mathrm{g}$, respectively. The differences among the findings of the studies could be variations in storage temperature, time of sample collection, location of the study sites and handling practices of the venders (Tambekar et al., 2009). Improper handling and improper hygiene might lead to the contamination of food with Staphylococcus aureus and this might eventually affect the health of the consumers (Odu and Akano, 2012). Foods that require considerable handling during preparation and are kept at slightly elevated temperatures after preparation are frequently the ones involved in staphylococcal food poisoning (Fahed, 2003). $S$. aureus is amongst the most common pathogens found on hands and there is every possibility of contamination before or after cooking of a food as well as during serving. Possible sources of contamination may account for washing water, insects and rodents, hair or hair products in food, unhygienic kitchen environment, contaminated equipment, contaminated air or dust and lack of adequate sanitation (Rabbi et al., 2011).

The prevalence of $S$. aureus in this study was $47(78.3 \%)$ of the total sample analyzed (Table 7). The results were contrary to the findings of Mirriam et al. (2012) who reported low prevalence of Staphylococcus aureus $(3.2 \%)$ in street-vended foods. On the contrary, in a study conducted in Malaysia, coagulase-positive Staphylococci were not found in all the examined samples (Alyaaqoubi et al., 2009). Similarly, Hanashiro et al. (2005) stated that Staphylococci were not detected in street-prepared RTE meal samples in Brazil. Differences in geographical location and personal hygiene of the food handlers might help to explain this variation. When Staphylococcus aureus is allowed to grow in foods, it can produce a toxin that causes illness. Although, cooking destroys the bacteria, the toxin produced by Staphylococcus aureus is heat stable and may not be destroyed even by heating, let alone by refrigeration. Foods that are handled frequently during preparation are prime targets for Staphylococci contamination (Ghosh et al., 2004).

As the result of the current study, out of isolates of Staphylococcus aureus, only 4 (13.3\%) of legume based and $3(10 \%)$ of vegetable based food were hazardous (Table 8 ) due to S.aureus $\geq 10^{4}$ based on (NSW, 2009). Compared this finding with the study done in Accra, $31.9 \%$ of $S$. aureus out of total samples of street vended foods was isolates (Mensah et al., 2002) and in another study, it was observed that, only $16 \%$ of street vended RTE food contaminated with $S$. aureus (Umoh and Odoba, 1999). The presence of $S$. aureus in high numbers $(>4 \log 10 / \mathrm{g})$ in ready to eat foods may indicate a possible contamination either after cooking or under processing. While the remaining of the food samples as satisfactory level in which, 13(43.3\%) and $9(30 \%)$ of legume based food categorized as good, and acceptable, respectively, and similarly $7(23.3 \%)$ and $11(36.7 \%)$ of vegetable food categorized as good, and acceptable, respectively (Table 8).

Table 8: The number and percentage of good, acceptable and unsatisfactory level of $S$. auerus count in street vended legume and vegetable based foods in Bahir Dar town

\begin{tabular}{llllccc}
\hline Parameter & Food type & Good $(\%)$ & Acceptable $(\%)$ & $\begin{array}{c}\text { Unsatisfactory } \\
(\%)\end{array}$ & $\begin{array}{c}\text { Hazardous } \\
(\%)\end{array}$ & Total \\
\hline \multirow{2}{*}{ S. auerus } & Legume & $13(43.3 \%)$ & $9(30 \%)$ & $4(13.3 \%)$ & $4(13.3 \%)$ & 30 \\
& Vegetable & $7(23.3 \%)$ & $11(36.7 \%)$ & $9(30 \%)$ & $3(10 \%)$ & 30 \\
Total & & $20(33.3 \%)$ & $20(33.3 \%)$ & $13(21.7)$ & $7(11.7 \%)$ & 60 \\
\hline
\end{tabular}

As shown in (Figure 4), the mean count of $S$.aureus $(\log 10 \mathrm{cfu} / \mathrm{g})$ in legume based food, lower count from Hospital area $(2.35 \log 10 \mathrm{cfu} / \mathrm{g})$, Bus station $(3.06 \log 10 \mathrm{cfu} / \mathrm{g})$ followed by Belay zeleke kebele (3.61 $\log 10$ $\mathrm{cfu} / \mathrm{g})$ was recorded. There were statistical significant differences in legume based food among three sites $(\mathrm{f}=6$; $\mathrm{p}=0.01$ ). Similarly, mean count of $S$. aureus in vegetable based food was $2.37,2.94$ and $3.24 \log 10 \mathrm{cfu} / \mathrm{g}$ from Hospital, Bus station and Belay zeleke kebele, respectively. There was also a statistical significant difference in count of $S$. aureus in vegetable based food among three sites $(f=4.059 ; p=0.031)$. The reasons for bacterial count 
differences among sites may be due to handling practice and personal hygiene of vendors as well as time and temperature abuse.

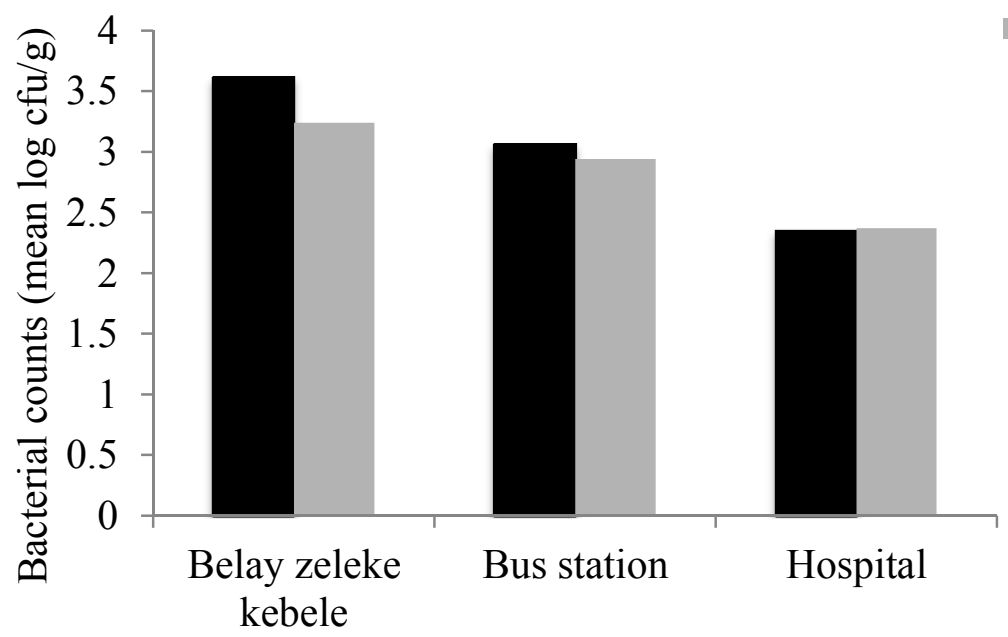

Legume based food

Vegetable based food

Study site

Figure 4: S. aureus counts $(\log 10 \mathrm{cfu} / \mathrm{g})$ of street vended legume and vegetable based foods among three sites in Bahir Dar, 2013

\section{Bacteriological analysis of water}

The water samples collected, along with the food samples, were those presented for drinking, washing utensils for serving the foods and hand washing. Water gets contaminated in the household during storage or time of fetching. The contaminated water samples could be the direct sources of enteric pathogens or they could introduce pathogens to the foods through serving plates when water is used for washing (Ray, 2004). The present study showed that total coliform counts of the water sample varied from $<2$ and $>1600 \mathrm{MPN} / 100 \mathrm{ml}$ in different sites. The result revealed that the bacteriological quality of only two of water samples analyzed ( $<2 \mathrm{MPN} / 100 \mathrm{ml})$ was within the acceptable limits based on WHO (2001) guidelines and the remaining water samples were above the acceptable limit in which four samples were above the upper detection limit $(>1600 \mathrm{MPN} / 100 \mathrm{ml}$. The WHO (2001) and Ethiopian drinking water guidelines (FDRE, 2011) require there should be no coliform bacteria/100 ml of treated water in the distribution as tested by multiple tube tests.

According to Nawas et al. (2012), 33.33\% of water samples had a total coliform count more than 1100 $\mathrm{CFU} / 100 \mathrm{ml}$ and $73.33 \%$ of the samples were contaminated with total and fecal coliform bacteria, which were unacceptable for human consumption. The water used to prepare the foods and to clean the eating utensils sometimes may be sources of contamination because venders can use waste water as recycled for washing and cleaning purpose (Ray, 2004; Muhammed et al., 2010). Although coliform organisms may not always be directly related to the presence of fecal contamination, the presence of coliforms in water suggested the potential presence of pathogenic enteric microorganisms such as Salmonella spp., Shigella spp., and Vibrio cholera. Thus, water quality can greatly influence the microbial quality of foods. In addition to bacteria, contamination of foods with pathogenic viruses, and parasites from water is commonly reported (Ray, 2004; Muhammed et al., 2010).

\section{Assessments of the hygienic practices of venders and the vending environment}

Vendors handling practices, personal hygiene and the vending environment have been significant role for contamination of street vended RTE food. In the present study, $21(58.3 \%)$ and $24(66.7 \%)$ did not dress appropriate overcoat and hair cover, respectively (Table 10). Because hair is known to harbor S. aureus, it is essential to prevent loose hair, and dandruff from falling onto the food or food preparation areas (Lues et al., 2006). Twenty three $(63.9 \%)$ of the venders were observed had no short and cleaned nail and majority of the food handlers achieved their activity without proper and clean dressing (Table10) in which the food can get contaminated with $S$. aureus during preparation and handling of foods. Conversely, hand washing is an essential component of infection control (Larson, 2003). During the study, observations revealed that $27(75 \%)$ of the vendors did not practice hand washing while preparing and serving street foods, even the remaining $9(25 \%)$ of the venders wash their hands without the use of soap. Another study demonstrated that out of 128 street vendors in Indonesia, $70(55 \%)$ of the vendors did not wash their hands before food preparation. Although vendors washing their hands after defecation during working hours, non-use of soap or Sanitizers (Vollaard et al., 2004). This could have promoted transfer of the pathogens from the hand to the food (Taulo et al, 2008). Wear of 
jewelry was observed in $29(80.6 \%)$ of the vendors (Table 10). Overall, personal hygiene should be kept because street vendors are the largest contamination sources of food.

Table 10: Vendors' personal hygiene, in Bahir Dar town

\begin{tabular}{lcc}
\multicolumn{1}{c}{ Characteristics } & \multicolumn{2}{c}{ Frequency (n=36) } \\
Wearing of appropriate over coat & Yes & No \\
\hline Vendors dressed clan & $15(41.7 \%)$ & $21(58.3 \%)$ \\
Wear of appropriate hair cover & $17(47.2 \%)$ & $19(52.8 \%)$ \\
Short trimmed and cleaned nail & $12(33.3 \%)$ & $24(66.7 \%)$ \\
Hand washing before serving the food to the consumer & $13(36.1 \%)$ & $23(63.9 \%)$ \\
Wear of jewelry & $9(25 \%)$ & $27(75 \%)$ \\
\hline
\end{tabular}

In the present study, all of the vendors handling money when serving food (Table 11) can increase the chance of cross contamination into the foods. Similar observation in Nairobi, Kenya was stated by Muinde and Kuria (2005), all the vendors handled money while serving food. In this study, the majority of the food handlers $(88.9 \%)$ recycles water for several times without replacement of clean equipment (Table 11) which agreed with the study done by Comfort (2010) and Vollaard et al. (2004) stated that vendors renewing the dishwater in buckets up to 20 times during working hours. Most of the street food vendors cleaned their utensils with stored water without replacement in buckets before serving the food and this practice makes pathogens can be transferred to food from utensils with contaminated water. Therefore the water might have contaminated the utensils during cleaning and then cross-contaminated the food, as revealed by high incidence of pathogens in the street food (Taulo et al., 2008).

Table 11: Vendors' food handling practices in Bahir Dar town, $2013(\mathrm{n}=36)$

\begin{tabular}{lll}
\hline Characteristics & Frequency & Percent \\
\hline Food reheats before sale & - & 100 \\
Yes & 36 & 41.7 \\
No & & 58.3 \\
Adequate cooking of the foods & 15 & - \\
Yes & 21 & 100 \\
No & & 30.6 \\
Left over RTE foods stored at refrigerated temperature & - & - \\
Yes & 36 & 69.4 \\
No & & - \\
Modes cleaning and sanitizing utensils : & 11 & 11.1 \\
Hot water with detergent & - & 88.9 \\
Only cold water without detergent \\
How many times water used for washing dish : & 25 & 100 \\
Once & & - \\
Swice & - & \\
Yeveral & 32 & \\
Yes & & \\
\hline
\end{tabular}

In contrast the present study showed that, none of the outlets were using refrigerators to store RTE foods after cooking or raw foods before cooking and again, none of the vendors reheated food before serve to consumers and only $11(30.6 \%)$ of the vendors did use cold water with soap and the remaining without detergent to clean and sanitize utensils (Table 11). Another study conducted in Ghana remarked that, only $3(6 \%)$ vendors, keeping of leftover food in the refrigerator and the remaining were no refrigerators (Annan et al., 2011). Conversely, Mensah and others (2002) reported that $7 \%$ of the vendors were used refrigerators to store the poultry before cooking.

Infrequent hand washing, non-use of soap, direct hand contact with foods and inadequate dishwashing in food stalls are likely to result in bacterial contamination of street food. From the literature, it is evident that proper hand washing is one of the most effective measures to control the spread of pathogens in food handling (Montville et al., 2002).

In the current observation, most of the street food outlets were located near the road and some of them were near the municipal garbage bin for this reason only $11(30.6 \%)$ of the vendors disposed liquid waste into municipal sewage whereas the remaining $25(69.4 \%)$ of the vendors disposed into the vending area (open 
dumping) as a result a dirty environment that attracted houseflies, the presence of which compromise sanitation. The presence of flies is an indication of poor hygiene and sanitary practices. Although most of the vending area had refused receptacles for solid waste, only a few had proper covering of the refuse receptacle and the receptacle could not far from the vending site (Table 12). Inadequate disposal of waste water and garbage derived from street food vending also adds to the potential for microbial disease transmission, partly by encouraging the proliferation of insects and rodents linked to enter disease transmission (Arambulo et al., 1994). On the other hand, 27 (75\%) of the food vendors buy water from privately installed pipe and only $9(25 \%)$ venders privately installed from a municipal supply, and also most of the venders encounter problem of shortage of water near the vending site (Table 12). According to FAO (1999), adequate drainage and waste disposal systems and other facilities should be provided in the street food industry and designed properly so that the risk of contamination of food and potable water could be minimized.

Table 12: Assessments of vending environment in Bahir Dar town, 2013 ( $n=36)$

\begin{tabular}{|c|c|c|}
\hline Characteristics & Frequency & percent \\
\hline \multicolumn{3}{|l|}{ Presence of refuse receptacles for solid waste } \\
\hline Yes & 30 & 83.3 \\
\hline No & 6 & 16.7 \\
\hline \multicolumn{3}{|l|}{ Proper covering of the refuse receptacle } \\
\hline Yes & 8 & 22.2 \\
\hline No & 28 & 77.8 \\
\hline \multicolumn{3}{|c|}{$\begin{array}{l}\text { Presence of a drainage system for collection and handling of } \\
\text { liquid Waste }\end{array}$} \\
\hline Yes & 9 & 25 \\
\hline No & 27 & 75 \\
\hline \multicolumn{3}{|l|}{ Harbor vectors such as flies? } \\
\hline Yes & 23 & 63.9 \\
\hline No & 13 & 36.1 \\
\hline \multicolumn{3}{|c|}{ Are the refuse receptacles far from the vending site? } \\
\hline Yes & 5 & 13.9 \\
\hline No & 31 & 86.1 \\
\hline \multicolumn{3}{|l|}{ Source of water : } \\
\hline Privately installed from municipal supply & 9 & 25 \\
\hline From communal distribution & - & - \\
\hline Buy from privately installed pipe & 27 & 75 \\
\hline From tanker & & \\
\hline \multicolumn{3}{|l|}{ Final Disposal of liquid waste: } \\
\hline Open dumping in the area & 25 & 69.4 \\
\hline Septic tank & - & - \\
\hline Municipal sewage & 11 & 30.6 \\
\hline \multicolumn{3}{|l|}{ Latrin facilities : } \\
\hline Flush type & - & - \\
\hline Dry pit latrines & 20 & 55.6 \\
\hline Open latrines around the vending area & 9 & 25 \\
\hline Not available & 7 & 19.4 \\
\hline
\end{tabular}

The present study suggested that, the surroundings of the vending sites were not predominantly clean; in other ways, quality of street foods is affected due to exposure of food to fly; working with food at ground level; and inadequate cooking results in the survival of bacterial pathogens; cooking utensils can also add to the bacterial load (Mensha et al., 2002).

Safe food storage temperatures rarely applied to street foods; the present study showed that all of the food handlers store both raw and ready to eat food at ambient temperature for several hours and without care. Similarly, a study carried out by Muinde and Kuria (2005) stated that, vendors after preparing the food, kept it at ambient temperatures and serve it without heat at high temperatures and these practices enhance high microbial load. On the other hand, most of the street vendors are less educated, rough methods and work under crude unsanitary conditions might be cause of heavy contaminations of pathogenic bacteria in street vended foods which lead to food borne diseases for consumers (Feng et al., 2001). Overall, the level of microbial contamination has been increased from improper sanitation practices and lack of proper storage during the processing and selling period. 


\section{CONCLUSION}

In this study, the majority of the food samples contaminated with fecal coliforms, Staphylococcus aureus, aerobic mesophilic bacteria and total coliforms indicating the poor bacteriological quality of foods and a possible postcooking contamination. Even if most of the food samples were within satisfactory and acceptable quality range, high count of mean aerobic mesophilic bacteria and total coliforms were obtained from the area around Bus station and high mean count of $S$. aureus and fecal coliforms were detected around Belay zeleke kebele and Bus station. In turn, bacteriological analysis of water samples which used for washing equipment and food preparation implies all most all of the samples were unsatisfactory and unfit for use or consumption. Absence of tap water near the vending site, lack of liquid waste disposal, lack of hand washing and proper hair coat besides other facilities were some problems in the study area during observation. So special attention should be given environmental hygiene and handling practices. Good food practices, such as adequate cooking, hygienic food processing and proper handling can greatly minimize the risk of food contamination.

\section{REFERENCES}

Abdella MA, Suliman SE, Bakhiet AO. 2009. Food safety knowledge and practices of street food vendors in Atbara City, Sudan state. African Journal of Biotechnology, 24: 6967-6971

Adetunde LA, Glover RLK. 2011. Evaluation of bacteriological quality of drinking water used by selected secondary schools in Navrongo in Kassena-Nankana district of upper east region of Ghana. Prime Journals of Microbiology Research, 1(3): 47-51

Agard L, Alexander C, Greens S, Jackson M, Patel S, Adesiyun A. 2002. Microbial quality of water supply to an urban community in Trinidad. Journal of Food Protection, 65:1297-1303.

Alemayehu Getahun. 2011. Microbiological quality and safety of meat sauce in Bahir Dar town. MSc. Thesis, Bahir Dar University.

Alyaaqoubi SJM, Abdullah SN, Abdullah A, Abdulrahman RD. 2009. Microbiological quality of selected readyto-eat food at hulu langat district, Malaysia. Food Sciences, 9 (11): 421-433

Andrews, W. 1992. Manual of Food Quality Control. Food and Agriculture Organization of the United Nations (FAO). Rome.

Annan AP, Amewowor DH, Kofi JO, Amoono SE, Akorli SY, Saka E and Ndadi HA. 2011. Street foods: handling, hygiene and client expectations in a World Heritage Site Town, Cape Coast, Ghana. African Journal of Microbiology Research, 5 (13): 1629-1634

Arambulo P, Almeida J, Belotto AJ. 1994. Street food vending in Latin America. Bulletin of Pan American Health Organization, 28 (4): 344-354.

Azanza P. 2005. Aerobic plate counts of philippine ready-to-eat foods from take-away premises. Journal of Food Safety, 25: 80-97.

Bahir Dar City Administration (2009), Basic Information, the City Administration of Bahir Dar, Bahir Dar.

Barro N, Bello AR, Aly S, Ouattara T, Iboudo AJ, Traore AS. 2006. Hygienic status assessment of dish washing waters, utensils, hands and pieces of money from street food processing sites in Ouagadougou (Burkina Faso). African Journal of Biotechnology, 5 (11):1107-1112.

Bukar A, Uba A, Oyeyi TI. 2010. Occurrence of some enteropathogenic bacteria in some minimally and fully processed ready to eat foods in Kano metropolis, Nigeria. African Journal of Food Science, 4 (2): 32-36.

Comfort OC. 2010. Food safety and hygienic practices of street food vendors in Owerri, Nigeria. Studies in Sociology of Science, 1 (1):50-57.

Deriba Muleta, Mogessie Ashnafi. 2001. Salmonella, Shigella and growth potential of other food-borne pathogens in Ethiopian street vended foods. East Africa Medical Journal, 78 (11):576-580.

Draper A. 1996. Street foods in developing countries: the potential for micronutrient fortification. London School of Hygiene and Tropical Medicine.

Fang TJ, Wei QK, Liao CW, Hung MJ, Wang TH. 2003. Microbiological quality of $18^{\circ} \mathrm{C}$ ready-to-eat food products sold in Taiwan. International Journal of Food Microbiology, 80: 241-250.

FAO. 1999. Draft revised guidelines for the design of control measures for street-vended foods in Africa. FAO, Rome.

FDRE. 2011. Federal Democratic Republic of Ethiopian, Ministry of health. National drinking water quality monitoring and surveillance strategy, drinking water specification, Addis Ababa.

Feglo P, Sakyi K. 2012. Bacterial contamination of street vending food in Kumasi, Ghana. Journal of Medical and Biomedical Sciences, 1(1): 1-8.

Feng P, Weagant S, Grant M. 2001. Bacteriological Analytical Manual, $8^{\text {th }}$ Edition, FDA. Food. Annals, series Historia et Sociologia, 13(1): 87-102.

Food quality check program. 2011. Microbiological recommendations. Food Laboratory, Environmental Microbiology BC Public Health Microbiology and Reference Laboratory.

Garode AM, Waghode SM. 2011. Bacteriological status of Street-Vended foods and Public Health Significance: 
A Case study of Buldana District, MS, India. Journal of Biological Sciences, 1 (3): 69-71.

Ghosh M, Mudgil S, Ganguli A. 2004. Microbiological quality of carrots used for preparation of fresh squeezed street vended carrot juices in India. Journal of Food Agricultural and Environmental, 2:143-145.

Gitahi MG, Wangoh J, Njage PMK. 2012. Microbial Safety of Street Foods in Industrial Area, Nairobi. Research Journal of Microbiology, 7: 297-308.

Hanashiro A, Morita M, Matte GR, Matte MH, Torres EA. 2005. Microbiological quality of selected street foods from a restricted area of Sao Paulo city, Brazil. Food Control, 16: 439-444.

Kaul M, Agarwal G. 1998. Microbial load of common chat products. Indian Journal of Nutrition and Diet, 25:197-199.

Kiiyukia C. 2003. Laboratory Manual of Food Microbiology for Ethiopian Health and Nutrition Research institute. YA/ETH/03/436/11-52.

Leonard T, Susil L, Satya RS. 2003. Energy and Street Food, Project Completion Report.

Lu Lues JFR, Rasephei MR, Venter P, Theron MM. 2006. Assessing food safety and associated food handling practices in street food vending. International Journal of Environmental Health Research, 16 (5): 319 - 328.

Mastewal Balew. 2011. Microbiological quality and safety of ready to eat spaghetti and spaghetti sauce in Bahir Dar. MSc. Thesis, Bahir Dar University.

Mensah P, Yeboah MD, Owusu DK, Ablordey A. 2002. Streets foods in Accra, Ghana: How safe are they? Bulletin of the World Health Organization, 80: 546-554.

Mesfin Angaw. 2011. Microbiological quality and safety of Sambusa and Fried fish in Bahir Dar. MSc. Thesis, Bair Dar University, Faculty of applied microbiology

Mirriam EN, Collins EO, Nicoline FT, Ezekiel G, Roland NN. 2012. Food borne Pathogens Recovered from Ready-to-Eat Foods from Roadside Cafeterias and Retail Outlets in Alice, Eastern Cape Province, South Africa. International Journal of Environmental Resources and Public Health, 9: 2608-2619.

Mogessie Ashenafi. 2002. The Microbial Spoilage of some Traditional Ethiopian Sauces at Ambient Temperature. SINET: Ethiopian Journal of Science, 25:97-140.

Montville R, Chen Y, Schaffner DW. 2002. Risk assessment of hand washing efficacy using literature and experimental data. International Journal of Food Microbiology, 73: 305-313.

Muinde O, Kuria E. 2005. Hygienic and sanitary practices of vendors of street foods in Nairobi, Kenya. Journal of Food and Agriculture, 5 (1):1-14.

Mulugeta Kibret, Million Tadesse. 2013. The bacteriological safety and antimicrobial susceptibility of bacteria isolated from street-vended white lupin (Lupinus albus) in Bahir Dar, Ethiopia. Ethiopian Journal of Health Science, 23 (1):19-26.

Nawas T, Mazumdar RM, Das S, Nipa MN, Islam S, Bhuiyan HR and Ahmad L. 2012. Microbiological Quality and Antibiogram of E. coli, Salmonella and Vibrio of Salad and

Water from Restaurants of Chittagong. Journal of Environmental Science and Natural Resources, 5 (1): 159 166.

Odu NN, Akano UM. 2012. The Microbiological Assessment of Ready-To-Eat-Food in Port Harcourt City, Nigeria. Nature and Science, 10 (8): 1-8.

Omemu A, Aderoju A. 2008. Food safety knowledge and practices of street food vendors in the city of Abeokuta, Nigeria. Food Control, 19: 396-402.

Omemu AM, Edema MO, Bankole MO. 2005. Bacteriological assessment of street vended ready to eat vegetables and prepacked salad in Nigeria. Nigerian Journal of Microbiology, 19 (2): 497-504.

PHLS, Public Health Laboratory Service. 2000. Guidelines for the bacteriological quality of ready to eat foods Microbial Quality of Ready-to-Eat Foods Available to sample at the point of sale, Communicable Diseases and Public Health 3(3):163-167.

Rabbi FA, Rabbi F, Runun TA, Zaman K, Rahman MM, Noor R. 2011. Microbiological Quality Assessment of Foods collected from Different Hospitals within Dhaka City. Stamford Journal of Microbiology, 1(1):31-36.

Ray B. 2004. Fundamental Food Microbiology, $3^{\text {rd }}$ ed. CRC Press LLC, Washington.

Roberts D, Greenwood M. 2003. Practical Microbiology, Third Edition, USA, Blackwell Publishing Inc.

Tambekar DH, Jaiswal VJ, Dhanorkar PB, Dudhane MN. 2009. Microbial quality and safety of street vended food: A case study of Amravati city. Internet Journal of Food Safety, 10: 72-76.

Taulo S, Wetlesen A, Abrahamsen R, Kululanga G, Mkakosya R, Grimason A. 2008. Microbiological hazard identification and exposure assessment of food prepared and served in rural households of Lungwena, Malawi. International Journal of Food Microbiology, 125: 111116.

Tekletsadik S, Tsige K. 2011. Microbiological safety of street vended ayib in Jimma town, southwest Ethiopia. Ethiopian Journal of Education and Science, 7 (1):81-91.

Thomas JM. 2010. Food microbiology, in Access Science @ McGraHill, http://www. Access science.com, DOI 10.1036/1097-8542.267000.

Umoh VJ, Odoba MB. 1999. Safety and quality evaluation of street foods sold in Zaire, Nigeria. Food Control, 
10: $9-14$.

Vollaard AM, Ali S, Van asten HA, Suhariah II, Widjaja S, Visser LG, Surjadi CH and Van Dissel JT. 2004. Risk factors for transmission of food borne illness in restaurants and street vendors in Jakarta, Indones'ia. Epidemiology and Infection, 132 (5): 863872.

WHO. 2001. Guidelines for Drinking Water Quality, $2^{\text {nd }}$ ed. Vol 1: Microbiological Methods. World Health Organization, Geneva.

WHO. 2010. Basic steps to improve safety of street-vended food. Geneva: WHO.

Yasin N, Khan J, Shah N, Azim Khan R, Saba N. 2012. Bacteriological study of food in the Pakistan's periurban areas of Rawalpindi and Islamabad. African Journal of Biotechnology, 11(39): 9445-9451. 